Bellett, A. J. D. \& Cooper, P. D. (1959). J. gen. Microbiol. 21, 498-509

\title{
Some Properties of the Transmissible Interfering Component of Vesicular Stomatitis Virus Preparations
}

\author{
By A. J. D. BELLETT* AND P. D. COOPER $\dagger$ \\ Wright-Fleming Institute of Microbiology, St Mary's Hospital, London, W. 2
}

\begin{abstract}
SUMMARY: In vesicular stomatitis virus inocula containing the transmissible interfering component ( $T$ ) an exponential relation, at low doses, between inoculum concentration and virus yield suggested that adsorption of one $T$ particle was enough to exclude infective virus. This relation was not maintained at high doses of inoculum, possibly because maximal interference required several hours between adsorption of T and virus particles. An assay method for $\mathbf{T}$, based on the dose which gave $37 \%$ of the yield from $T$-free inocula, showed that the $T$ content of inocula was usually related to passage history and yield of virus on undiluted passage. Treatment with immune serum did not appear to neutralize $T$, which sedimented in the centrifuge more slowly than did virus. $T$ was much less rapidly inactivated at $56^{\circ}$ and by u.v. irradiation than was the infectivity. Despite resemblances between the agent $\mathbf{T}$, incomplete influenza virus and interferon, direct evidence is lacking that $T$ is an incomplete form of the vesicular stomatitis virus or an interferon-like substance.
\end{abstract}

In a previous paper (Cooper \& Bellett, 1959) we described a phenomenon with vesicular stomatitis virus which resembled the interference due to 'incomplete' virus in influenza (von Magnus, 1951). It was concluded that the low yields from serial undiluted passage of virus were due to a transmissible interfering component $(\mathrm{T})$. The present paper attempts a further definition of the properties of the agent $T$, and a comparison of $T$ with incomplete influenza virus and influenza interferon (Isaacs \& Lindenmann, 1957).

\section{METHODS}

The preparation ' of media, virus stocks and tissue cultures, and the assay of virus by plaque count were described previously (Cooper, 1957; Cooper, $1958 a$; Cooper \& Bellett, 1959). Virus titres are expressed as plaque-forming units (pfu)/ml., dilutions being made in phosphate-buffered saline (PBS).

Assay of the interfering agent $T$. Samples $(0.5 \mathrm{ml}$.) of the virus stock to be assayed in twofold serial dilutions in the medium composed of Earle's saline $+5 \mathrm{mg}$. lactalbumin hydrolysate $/ \mathrm{ml} .+2 \mathrm{mg}$. yeast extract $/ \mathrm{ml} .+5 \%$ $(\mathrm{v} / \mathrm{v})$ horse serum were added to washed confluent $(20 \mathrm{hr}$.) chick embryo cell monolayers. After $1 \mathrm{hr}$, at $37^{\circ} 5 \mathrm{ml}$. of 'conditioned' medium (fluid from $20 \mathrm{hr}$. monolayers) were added, and $20 \mathrm{hr}$. later the supernatant fluids were removed and plaque-assayed immediately, or after 2-4 days at $-20^{\circ}$. The derivation of the content of $\mathrm{T}$ agent from these values is discussed below.

* Present address: Virus Research Group, M.R.C. Laboratories, Carshalton, Surrey.

$\dagger$ Present address: Virus Culture Laboratory, M.R.C. Laboratories, Carshalton, Surrey. 
Immune serum. Standardized hyperimmune guinea-pig sera prepared with the Indiana or New Jersey serotypes of vesicular stomatitis virus were kindly supplied by Dr J. B. Brooksby (Research Institute, Pirbright, Surrey). These sera in a final dilution of $1 / 300$ prevented plaque formation by homotypic virus, but not by heterotypic virus.

Complement-fixation tests. Complement-fixation tests (Brooksby, 1952) determined colorimetrically the haemolysis of sensitized sheep erythrocytes by complement left unfixed by antigen + serum mixtures. A series of $1 \mathrm{ml}$. volumes of 1.25-fold dilutions of preserved guinea-pig serum (Wellcome Laboratories) in veronal buffer was incubated for $1 \mathrm{hr}$. with $\mathbf{0 . 2} \mathrm{ml}$. antigen and $0.4 \mathrm{ml}$. of $1 / 16$ dilution of hyperimmune serum in colorimeter tubes in a water bath at $37^{\circ}$. Haemolytic serum (Wellcome Laboratories) diluted 1/100 was added to an equal volume of $3 \%(\mathrm{v} / \mathrm{v})$ sheep red blood cells and put in a water bath at $37^{\circ}$ for $30 \mathrm{~min}$. Two $\mathrm{ml}$. of this sensitized red cell suspension were added with mixing to each colorimeter tube, and the tubes were left at $37^{\circ}$ for a further $30 \mathrm{~min}$. for haemolysis, then centrifuged at $2000 \mathrm{rev} . / \mathrm{min}$. for $5 \mathrm{~min}$. and the colour of the supernatant immediately compared with distilled water in a Hilger-Spekker absorptiometer using a green filter. The points of $50 \%$ haemolysis were obtained graphically using a probit plot and compared with a control complement titration to calculate the amount of complement fixed. Results (Table 6) are expressed in arbitrary units/ml., the units representing the difference between relative concentrations of complement required to give $50 \%$ haemolysis in presence and absence of antigen (concentration in absence of antigen $=1$ ).

High-speed centrifugation to separate $\boldsymbol{T}$ from infective virus. Samples of undiluted passage virus stocks $(3 \mathrm{ml}$.) were added to $5 \mathrm{ml}$. capacity glass centrifuge tubes which each contained $1 \mathrm{ml}$. of solidified agar gel $(20 \mathrm{~g}$./1. distilled water), and centrifuged at 13,500-14,000 rev./min. for $65 \mathrm{~min}$. in a high-speed angle head ('International' refrigerated centrifuge) at $5^{\circ}$. The top $2 \mathrm{ml}$. of the supernatant was withdrawn for assay of $\mathrm{T}$, plaque-forming units and complement-fixing activity.

\section{RESULTS}

The number of $T$ particles required to exclude virus

Cooper \& Bellett (1959) concluded that the low yields from serial undiluted passage of vesicular stomatitis virus stocks were caused by a transmissible interfering component, $T$. This will be considered to be particulate, even though it may be of molecular dimensions. Since it was also shown that the interference was mostly an all-or-none exclusion, where cells either released a normal yield or none at all, the ratio of the overnight yield from a T-containing inoculum to that from a $\mathrm{T}$-free control can be taken as approximately the proportion of cells which did not receive an effective dose of $T$. The $T$-free control can either be a dilute passage stock, or the T-containing stock diluted sufficiently to make first-cycle mixed infection between $\mathrm{T}$ and plaque-forming units negligible. 
A plot of the relative concentration of dilutions of $\mathrm{T}$ added to a series of monolayers (the stocks being serially diluted down to doses at which further dilution did not increase the yield) against the logarithm of yield relative to the maximum yield (multiplicity of infective virus being kept constant at 2.5) showed a negative exponential relationship between dose and cells remaining uninterfered with, suggesting that only one $T$ particle per cell was required to exclude virus (Fig. 1). Experiments with some other T-containing stocks (together with one which was free of T), similar to that of Fig. 1 except that multiplicity of infection was not constant, showed that this exponential relation applied generally at low, but very rarely at high, doses (Fig. 2). This is discussed in the next section.



Fig. 1



Fig. 2

Fig. 1. The effect of $T$ concentration on virus yield with a constant multiplicity of infective virus. Mixtures of NJ.UP. 17 and NJ.DP.12 were prepared so that each mixture contained $10^{8} \mathrm{pfu} / \mathrm{ml}$, while the T content varied from $3.2 \times 10^{8} / \mathrm{ml}$. to $2.7 \times 10^{8} / \mathrm{ml}$. Inocula of $0.5 \mathrm{ml}$. of each mixture were added to $20 \mathrm{hr}$. monolayers, $5 \mathrm{ml}$. medium added after $1 \mathrm{hr}$. adsorption at $37^{\circ}$, and the supernatants plaque-assayed after a further $20 \mathrm{hr}$. at $37^{\circ}$. The highest multiplicity of $\mathrm{T}$ was 4 particles per cell, but the multiplicity of infective virus was always 2.5 pfu/cell. Relative yield is calculated on the basis of $2 \times 10^{7}$ cells/monolayer, although not all cells yield virus.

Fig. 2. The effect of dilution of inoculum on yield for a number of virus stocks. $T$ and infective virus were thus both varied together. The values of $M$ refer to the multiplicity of infective virus with undiluted stock as inoculum (dose $=100) . \Delta=$ NJ.UP.17, $\Delta=$ NJ.UP.16 $a, \square=$ NJ.DP.12, $\square=$ NJ.DP.8, $\square=$ IND.UP.22, $0=$ NJ.DP., stock, not numbered. Relative yield is calculated on the basis of $2 \times 10^{2}$ cells/monolayer, although not all cells yield virus.

\section{The assay of $T$}

As mentioned above, the ratio between overnight yields from T-containing and $T$-free inocula can be taken as the proportion of cells which did not receive an effective dose of $\mathbf{T}$, provided that enough time is allowed for virus release from all unprotected cells to be complete. When a culture has received an 
average of one effective dose of $\mathrm{T} /$ cell, the proportion of cells not receiving an effective dose of T, i.e. the proportion of yielders, should equal $e^{-1}(=0 \cdot 37)$. Since 1 effective dose $=1$ particle (Figs. 1, 2), the inoculum dilution giving a $37 \%$ yield will contain about $4 \times 10^{7} \mathrm{~T}$ particles $/ \mathrm{ml}$., since $0.5 \mathrm{ml}$. is always added as inoculum to monolayers containing about $2 \times 10^{7}$ cells. From this the $\mathbf{T}$ content of the undiluted stock could be calculated; in those stocks with apparently low efficiencies of interference at high doses, the $37 \%$ yield was estimated from the low-dosage part of the curve. It must be recognized that (like plaque-forming units) the ' $\mathrm{T}$ particle content' is defined only by the assay system used, and, in common with any other biological activity estimated in terms of particles, is likely to represent a minimum due to probability effects and other causes of inefficient assay.

The following section shows that several such assays give results in agreement with expectations from undiluted passage yield and passage history of the stock. However, most assays involved simple serial dilution of the stock, so that low doses of $\mathbf{T}$ accompanied low doses of virus, and a later section suggests that an interval of several hours between receiving $T$ and plaqueforming units is needed for maximal interference. The reduced effectiveness of $\mathbf{T}$ at high doses may be because a small variable proportion of cells is insusceptible to $T$ but susceptible to virus, or because $T$ is antagonized by some component of the stock, but it is more likely to be because the higher doses infect more cells in the first cycle (i.e. within say $30 \mathrm{~min}$. of $\mathrm{T}$ ). If $\mathrm{T}$ requires more time than this to protect all cells, then those cells infected in the first cycle will be more likely to succumb to virus. In support of this are the two assays of T in NJ.UP.17 afforded by Figs. 1 and 2. In Fig. I all cells received plaque-forming units within a short time of $T$, and the apparent $T$ content was $1.5 \times 10^{8} \mathrm{~T}$ particles/ml.; in Fig. 2, at the dose giving $37 \%$ yield probably less than $1 \%$ of the cells received plaque-forming units within 4-5 hr. of T, and the apparent $\mathrm{T}$ content was $6 \cdot 4 \times 10^{8} \mathrm{~T}$ particles $/ \mathrm{ml}$.

Presumably this perturbation will not affect the $T$ assay if the curves are linear in that segment where the input multiplicity of live virus is appreciably less than 1. However, several curves are non-linear in this segment (Figs. 2,3), so that, unless $\mathrm{T}$ is still not fully established by the third cycle, some other factor may also neutralize $T$. Therefore, while this assay does permit some interpretations in terms of absolute $\mathbf{T}$ particle concentrations, one can summarize its defects as $(a)$ it requires a lengthy series of plaque assays and several assumptions, $(b)$ it is interfered with by infective virus, $(c)$ its reproducibility may be further affected by some other unknown factor.

\section{Relation between $T$ content, yield on undiluted passage and passage history}

This relationship is summarized for a number of stocks in Table 1. As may be expected from the data of Cooper \& Bellett (1959), stocks giving high yields on undiluted passage generally had high plaque-forming unit and low $\mathrm{T}$ contents, and stocks giving low yields had the reverse. Consequently, highyielding stocks often had low $\mathrm{T}$ :plaque-forming unit ratios and vice versa. 
Table 1 may suggest that this ratio is more closely related to undiluted passage yield than are absolute $\mathrm{T}$ or plaque-forming unit contents, but the data are here insufficient to show whether infective virus could compete with $\mathbf{T}$ and so neutralize the interference.

Table 1 also shows that serial undiluted passage usually resulted in a high, and dilute passage or a single undiluted passage a low, $\mathbf{T}$ content. The $\mathbf{T}$ content of dilute passage stocks depended on the dilution of passage, as may be expected, but some stocks passed at quite high dilutions (e.g. NJ.DP. 12) had a relatively high $\mathbf{T}$ content.

Table 1. Comparison of history of several vesicular stomatitis virus stocks with $\boldsymbol{T}$ content and autointerfering ability

IND. = Indiana serotype, .NJ. = New Jersey serotype, UP. = undiluted passage, DP. = dilute passage.

\begin{tabular}{|c|c|c|c|c|c|}
\hline Stock & $\begin{array}{l}\text { Yield on } \\
\text { undiluted } \\
\text { passage } \\
\text { (pfu/cell) }\end{array}$ & $\begin{array}{l}\text { T content } \\
\text { (particles/ } \\
\text { ml.) }\end{array}$ & $\begin{array}{c}\text { Infective } \\
\text { titre } \\
\text { (pfu/ml.) }\end{array}$ & $\begin{array}{l}\text { T:pfu } \\
\text { ratio }\end{array}$ & History \\
\hline IND.UP.22 & $\mathbf{5 0 0}$ & $4.8 \times 10^{7}$ & $2 \times 10^{9}$ & $1: 42$ & I UP from one pfu \\
\hline NJ.DP.14 & 375 & $<10^{7}$ & $2.6 \times 10^{9}$ & $1:>\mathbf{2 6 0}$ & 1 DP from one pfu \\
\hline IND.DP.3 & $60,72,205$ & c. $10^{9}$ & $8.2 \times 10^{0}$ & $1: 3 \cdot 2$ & $\begin{array}{l}1 \mathrm{UP}+1 \mathrm{DP}(1 / 3) \text { from } \\
\text { one pfu }\end{array}$ \\
\hline NJ.DP.8 & 10,250 & $3.1 \times 10^{8}$ & $2.7 \times 10^{9}$ & $1: 8 \cdot 8$ & $\begin{array}{l}1 \mathrm{DP}(1 / 2) \text { from original } \\
\text { stock }\end{array}$ \\
\hline IND.UP.13 & 70 & $5.6 \times 10^{8}$ & $2.4 \times 10^{8}$ & 2.3:1 & $\begin{array}{l}\text { Long UP + very low- } \\
\text { dilution passage series } \\
\text { from } 1 \text { pfu }\end{array}$ \\
\hline $\begin{array}{l}\text { NJ.UP.17 } \\
\text { plus }\end{array}$ & 55 & $1.5 \times 10^{8}$ & $1 \times 10^{8}$ & $1 \cdot 5: 1$ & $\begin{array}{l}\text { Artificial mixture of } \\
\text { NJ.UP. 17 plus }\end{array}$ \\
\hline NJ.DP.12 & & & & & NJ.DP. 12 \\
\hline IND.DP.24 & 22 & $2.5 \times 10^{8}$ & $2 \cdot 1 \times 10^{9}$ & $1: 8 \cdot 4$ & $\begin{array}{l}1 \mathrm{UP} \text { + } 3 \text { very high- } \\
\text { dilution passages from } \\
1 \mathrm{pfu}\end{array}$ \\
\hline NJ.DP.12 & 6 & $2.8 \times 10^{8}$ & $1 \times 10^{9}$ & $1: 3 \cdot 6$ & $\begin{array}{l}\text { Long high-dilution } \\
\text { passage series }\end{array}$ \\
\hline NJ.UP.16a & 2,2 & $\begin{array}{r}4 \times 10^{8} \\
8 \times 10^{8}\end{array}$ & $1.9 \times 10^{8}$ & $210: 1$ & $\begin{array}{l}\text { Long UP. or low-dilu- } \\
\text { tion passage series from } \\
1 \text { pfu }\end{array}$ \\
\hline NJ.UP.17 & $1 \cdot 6$ & $6.4 \times 10^{8}$ & $7 \cdot 2 \times 10^{6}$ & $89: 1$ & $\begin{array}{l}\text { Long UP. or low-dilu- } \\
\text { tion passage series from } \\
\text { I pfu }\end{array}$ \\
\hline
\end{tabular}

Time required for establishing exclusion by $T$

Although this time was not measured directly, some indications of its duration have been obtained. In one series of monolayers (Table 2) inoculated simultaneously with a constant amount of $\mathbf{T}$ and varying amounts of infective virus, those cultures with an average input multiplicity of infection considerably less than one gave a yield appreciably less than those with multiplicities around one, despite greater chances for thermal inactivation in the latter. 
Thus, although interference was present in all cultures, those cells which were not infected until 4-6 hr. after receiving $T$ (i.e. until the second cycle) were more resistant to the virus. The culture with the lowest inoculum showed some delay in cytopathic effect, a phenomenon never found with comparable inocula of dilute passage virus.

Table 2. Effect on yield of varying the multiplicity of infective virus, $T$ being kept constant

A series of monolayers was infected with $0.5 \mathrm{ml}$. each of mixtures containing constant amounts of $T$ but different amounts of plaque-forming units. After $45 \mathrm{~min}$., $5 \mathrm{ml}$. of medium were added, and the supernatants harvested for plaque assay after a further $20 \mathrm{hr}$.

$\begin{array}{lc}\overbrace{\text { pfu }}^{2} \text { Inoculum per cell } \\ 3.2 & \text { T particles } \\ 1.6 & 4.9 \\ 0.85 & 4.5 \\ 0.44 & 4.3 \\ 0.24 & 4.1 \\ 0.14 & 4.1 \\ 0.045 & 4.0 \\ & 4.4\end{array}$

$\begin{array}{cc}\begin{array}{c}\text { Yield } \\ \text { (pfu/cell) }\end{array} & \begin{array}{c}\text { Cytopathic } \\ \text { effect at } \\ \mathbf{2 0 ~ h r}\end{array} \\ \mathbf{1 8} & ++ \\ \mathbf{1 8} & ++ \\ \mathbf{4 2} & ++ \\ \mathbf{4 2} & ++ \\ \mathbf{5 \cdot 8} & ++ \\ \mathbf{9} \cdot \mathbf{0} & ++ \\ \mathbf{2 \cdot 0} & \pm\end{array}$

This protection was also found several times with undiluted passage virus where most cells were not infected in the first cycle (Cooper \& Bellett, 1959). In experiments where $T$ and plaque-forming units were added simultaneously to all cells, about $80 \%$ of cells were prevented from releasing virus, but not protected from cytopathic effect. We therefore conclude that the bulk of the exclusion is established within $1 \mathrm{hr}$. but that longer, perhaps $6-8 \mathrm{hr}$., is required to protect cells fully (especially from cytopathic effect). These times may well depend on relative multiplicities of $\mathbf{T}$ and plaque-forming units; interference is the resultant of the two processes of establishing 'infection' by $\mathrm{T}$ and by infective virus, and as mentioned by Cooper (1958b), one cannot deduce much about the rates of the two component processes from the apparent rate of establishing interference.

\section{Heterotypic interference by undiluted passage virus stocks}

Three groups of monolayers received either (a) Indiana virus alone, or (b) Indiana virus plus a little New Jersey virus plus New Jersey $\mathbf{T}$ particles in excess, or (c) Indiana virus plus the same small addition of New Jersey virus as an extra control (Table 3). All monolayers had the same multiplicity of Indiana virus. As the infective New Jersey virus was present in minor amounts and is less effective than Indiana virus in establishing exclusion (Cooper, $1958 b$ ), its contribution to yield and infective centres was ignored; immune serum was not used. Table 3 shows that the presence of undiluted passage New Jersey virus considerably depressed both yield and infective centres formed by Indiana virus, in amounts not due to the small presence of New Jersey infective virus. The interference was only partly accounted for by the 
decrease in the number of infective centres established by the dilute passage Indiana virus. Thus, undiluted passage New Jersey virus has a heterotypic interfering activity not shown by dilute passage New Jersey virus at the same multiplicity, although the relationship between the heterotypic excluding agent and $T$ remains to be demonstrated.

\section{Table 3. Heterotypic interference by undiluted passage virus stocks}

Three groups of identical $20 \mathrm{hr}$. monolayers received $0.5 \mathrm{ml}$. per monolayer of: Group 1 . Indiana virus alone (1.5 ml. IND.DP. 24 1/50 (PBS) $+1.5 \mathrm{ml}$. PBS, giving $2.1 \times 10^{2}$ IND. $\mathrm{pfu} / \mathrm{ml}$.); Group 2. Indiana virus + New Jersey virus + New Jersey T particles (1.5 ml. IND. DP. $241 / 50$ (PBS) $+1.5 \mathrm{ml}$. NJ.UP. 17, giving $2.1 \times 10^{7} \mathrm{IND}$. pfu/ml. $+3.6 \times 10^{6} \mathrm{NJ}$. pfu/ ml. $+3.2 \times 10^{8}$ NJ.T particles/ml.); Group 3. Indiana virus + T-free New Jersey virus in the same multiplicity of infection as group $2(1.5 \mathrm{ml}$. IND.DP. 24, 1/50 (PBS) +1.5 ml. NJ.DP. 12 1/100 (PBS), giving $2.1 \times 10^{7} \mathrm{IND}$. pfu/ml. $+5 \times 10^{6} \mathrm{NJ}$ pfu/ml.). After $30 \mathrm{~min}$. at $37^{\circ}, 2$ monolayers in each group received $5 \mathrm{ml}$. of conditioned medium (harvested for virus assay $20 \mathrm{hr}$. later), and the remaining 2 monolayers were harvested for total cell and infective centre assay (Cooper, 1958b). $M=$ multiplicity of infection.

\begin{tabular}{|c|c|c|c|c|c|c|}
\hline $\begin{array}{c}\text { Group } \\
\text { (1) }\end{array}$ & $\begin{array}{l}\text { Inocula } \\
\text { (2) }\end{array}$ & $\begin{array}{c}\text { Infective } \\
\text { centres/ } \\
\text { monolayer } \\
\times 10^{5} \\
(3)\end{array}$ & $\begin{array}{c}\text { Total } \\
\text { cells/ } \\
\text { monolayer } \\
\times 10^{7} \\
(4)\end{array}$ & $\begin{array}{c}\text { Mean* } \\
\text { plating } \\
\text { efficiency } \\
\text { (5) }\end{array}$ & $\begin{array}{c}\text { Total yield } \\
\text { (pfu/ } \\
\text { monolayer) } \\
\times 10^{8} \\
(6)\end{array}$ & $\begin{array}{c}\text { Mean } \dagger \\
\text { yield (pfu/ } \\
\text { infected } \\
\text { cell) } \\
(7)\end{array}$ \\
\hline 1 & $\left.\begin{array}{c}\text { IND virus } \\
(\mathbf{M}=0.5)\end{array}\right\}$ & $\begin{array}{l}5 \cdot 9 \\
6 \cdot 5\end{array}$ & $\begin{array}{l}1 \cdot 6 \\
1 \cdot 4\end{array}$ & $8 \cdot 2$ & $\begin{array}{l}120 \\
110\end{array}$ & 1580 \\
\hline 2 & $\begin{array}{c}\text { IND virus } \\
(\mathbf{M}=0 \cdot 5) \\
+ \text { NJ virus } \\
(\mathbf{M}=\mathbf{0} \cdot 09) \\
+ \text { NJ T particles } \\
(\mathbf{M}=8)\end{array}$ & $\begin{array}{l}1.9 \\
\text { 3.0 }\end{array}$ & $\begin{array}{l}1 \cdot 3 \\
1 \cdot 5\end{array}$ & $3 \cdot 4$ & $\begin{array}{c}2 \cdot 4 \\
15\end{array}$ & 280 \\
\hline 3 & $\left.\begin{array}{r}\text { IND virus } \\
(M=0.5) \\
+ \text { NJ virus } \\
(M=0.11)\end{array}\right\}$ & $\begin{array}{l}7 \cdot 5 \\
9 \cdot 4\end{array}$ & $\begin{array}{l}2 \cdot 8 \\
2 \cdot 8\end{array}$ & $9 \cdot 8$ & $\begin{array}{r}120 \\
30\end{array}$ & 860 \\
\hline
\end{tabular}
found.

* Plating efficiency = ratio of infective centres expected from inoculum: infective centres found. col. 3 is multiplied by $100 / 8 \cdot 2$.

\section{The failure of immune serum to neutralize heterotypic interference by undiluted passage virus stocks}

Three confluent monolayers received either (a) Indiana virus + Indiana T particles, $(b)$ Indiana virus + Indiana $\mathrm{T}$ particles + Indiana antiserum, or (c) medium alone, as primary inocula (Table 4). After adsorption they were challenged with New Jersey virus as secondary inocula, and the supernatant fluids assayed for New Jersey plaque-forming units after virus growth and release. Table 4 shows that the Indiana antiserum did not prevent the Indiana undiluted passage virus from interfering with growth of New Jersey virus. 
Table 4. The failure of immune serum to neutralize heterotypic interference

by undiluted passage virus stocks

Óne $20 \mathrm{hr}$. monolayer received $0.5 \mathrm{ml}$. IND.UP. $49\left(1.7 \times 10^{8} \mathrm{pfu} / \mathrm{ml}\right.$., $4.4 \times 10^{8} \mathrm{~T} / \mathrm{ml}$.), another received $0.5 \mathrm{ml}$. IND.UP. 49 plus $0.2 \mathrm{ml}$. Indiana antiserum (1/2 PBS), and a control monolayer received $0.5 \mathrm{ml}$. ES. After $30 \mathrm{~min}$. at $37^{\circ}, 0.5 \mathrm{ml}$. NJ.DP. 14 diluted $1 / 10 \mathrm{ES}\left(2.6 \times 10^{8} \mathrm{pfu} / \mathrm{ml}\right.$.) was added to each monolayer as secondary inoculum and $5 \mathrm{ml}$. medium were added $30 \mathrm{~min}$. later. The fluids were harvested and titrated $8 \mathrm{hr}$. after infection, Indiana antiserum ( $0.2 \mathrm{ml}$. of $1 / 10$ dilution in PBS) being added to the agar overlayers.

Primary inoculum

$0.5 \mathrm{ml}$. IND.UP. 49

$\{0.2 \mathrm{ml}$. IND. antiserum (1/2)

$\{+0.5 \mathrm{ml}$. IND.UP. 49

$0.5 \mathrm{ml}$. ES

$\begin{array}{cc}\text { Secondary inoculum } & \text { Yield (pfu/ml.) } \\ 0.5 \mathrm{ml} \text {. NJ.DP. 14 }\left(10^{-1}\right) & 5.2 \times 10^{7} \\ 0.5 \mathrm{ml} \text {. NJ.DP. 14 }\left(10^{-1}\right) & 3.4 \times 10^{6} \\ \text { 0.5 ml. NJ.DP. 14 }\left(10^{-1}\right) & 2.5 \times 10^{8}\end{array}$

\section{The effect of heat and ultraviolet treatment on homotypic interference} by undiluted passage virus stocks

Vesicular stomatitis virus minimally inactivated by heat or ultraviolet light, and therefore probably live virus also, does not interfere with the multiplication of infective virus of the same serotype if added simultaneously $($ Cooper, $1958 b)$. If an undiluted passage stock is treated with heat or u.v. it should therefore be possible to follow the effect of the treatment on the interfering ability of $\mathbf{T}$ without complication from interference by inactivated virus.

Table 5 describes an experiment in which a T-containing New Jersey stock was exposed to u.v. or heated at $56^{\circ}$ for varying times. After treatment samples

\section{Table 5. Heat and ultraviolet treatment of undiluted passage virus stocks}

A stock of NJ.UP.16 virus $\left(9 \cdot 0 \times 10^{7} \mathrm{pfu} / \mathrm{ml}\right.$.) was divided into $1 \mathrm{ml}$. samples in $5 \mathrm{ml}$. screw-capped bottles. One bottle was removed to $4^{\circ}$ in the dark as a control; some bottles were put in a $56^{\circ}$ water bath and others, with their caps removed, were put $50 \mathrm{~cm}$. below a Philips 30 W. u.v. lamp. All were frequently shaken. After the exposure times shown, samples were removed to $4^{\circ}$ in the dark and then titrated by plaque count. Half $(0.5 \mathrm{ml}$.) of each sample was added to a monolayer, with medium alone on another as control, and all were followed $10 \mathrm{~min}$. later by $0.25 \mathrm{ml}$. NJ.DP.14?diluted $1 / 2$ in medium (giving 16 pfu/ cell), and $5 \mathrm{ml}$. medium after a further $30 \mathrm{~min}$. at $37^{\circ}$. The yields were harvested and titrated $20 \mathrm{hr}$. later.

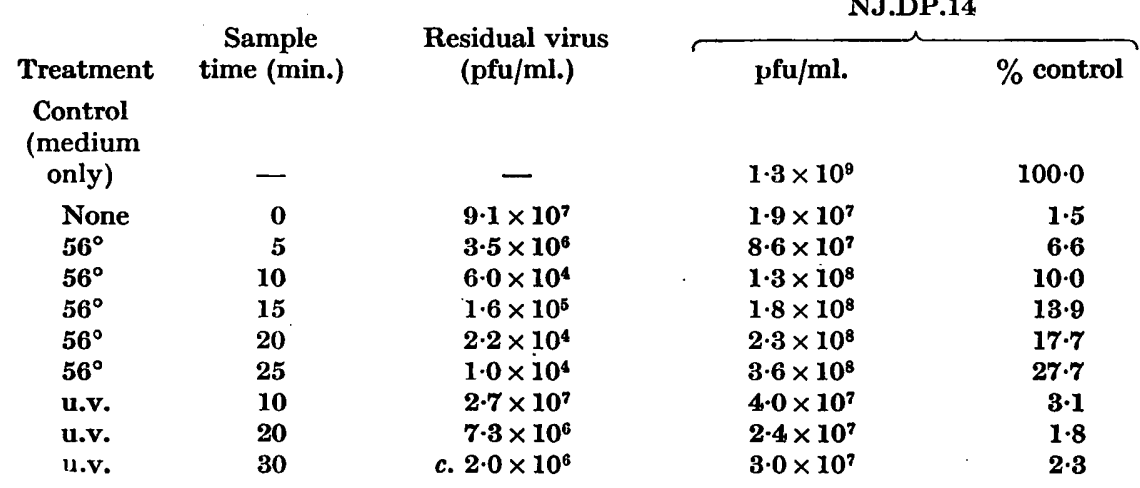

Yield from $0.5 \mathrm{ml}$. samples $+0.25 \mathrm{ml}$. NJ.DP.14 
were at once compared with an untreated control for plaque-forming unit contents, and the infectivity was found to decrease approximately exponentially with time of treatment in both cases. The full series of assays required for quantitative $\mathrm{T}$ comparisons were not performed, but the interfering abilities were compared by their effect on the overnight yield from a standard New Jersey inoculum. Table 5 shows that no detectable effect on interference followed a u.v. dose decreasing the plaque-forming unit content to $2 \%$ of the original. On the other hand, a large drop in infectivity at $56^{\circ}$ (to $10^{-4}$ of the original) accompanied a progressive but not complete drop in interfering activity. We conclude that $\mathrm{T}$ is much more stable to u.v. and $56^{\circ}$ inactivation than is the infectivity, but at doses equally lethal for infectivity a temperature of $56^{\circ}$ is probably a more effective inactivator of $T$ than is u.v.

\section{Separation of $\boldsymbol{T}$ and plaque-forming units by centrifugation}

Samples of clarified medium and disrupted cells from monolayers infected with a T-containing inoculum, harvested early ( $8 \mathrm{hr}$. after infection) to minimize contamination with 'soluble antigen', were centrifuged as described so as to sediment most but not all of the infectivity. The products were com: pared with uncentrifuged samples with respect to infectivity, $T$ content and complement fixation (Table 6 and Fig. 3). It was hoped thus to separate $T$

\section{Table 6. High speed centrifugation of an $8 \mathrm{hr}$. undiluted passage virus stock}

Four monolayers each received $0.5 \mathrm{ml}$. of NJ.UP. $16\left(9.0 \times 10^{7} \mathrm{pfu} / \mathrm{ml}\right.$.) and $5 \mathrm{ml}$. of conditioned medium after $1 \mathrm{hr}$, at $37^{\circ}$. The medium was harvested $8 \mathrm{hr}$. after infection; the monolayers were washed twice with PBS, the cells resuspended with trypsin (1.25 mg.) ml. in PBS without $\mathrm{Ca}^{++}$or $\mathrm{Mg}^{++}$), washed in PBS, pooled and suspended in $5 \mathrm{ml}$. PBS for disruption by twice freezing at $-60^{\circ}$ and thawing at $37^{\circ}$. Both medium and cell debris preparations were centrifuged at $3000 \mathrm{rev} . / \mathrm{min}$. for $15 \mathrm{~min}$.; $3 \mathrm{ml}$. of each supernatant were then recentrifuged at c. $14,000 \mathrm{rev} . / \mathrm{min}$. for $65 \mathrm{~min}$. in an International centrifuge at $5^{\circ}$, when the top $2 \mathrm{ml}$. were withdrawn and compared with the supernatant before high-speed centrifugation with respect to infectivity, $T$ content and complement fixation. The arbitrary complement-fixation units are described under 'Methods'; antiserum or antigen alone fixed negligible complement. The assay method for $T$ is described in the text, and the detailed results of the $T$ assays (relationship between yields and seed dilutions) are given in Fig. 3.

\begin{tabular}{|c|c|c|c|}
\hline Sample & $\begin{array}{c}\text { Titre } \\
\text { (pfu/ml.) }\end{array}$ & $\begin{array}{l}\text { Units } \\
\text { complement } \\
\text { fixed } / \mathrm{ml} \text {. }\end{array}$ & $\begin{array}{l}\text { T particles/ } \\
\text { ml. }\end{array}$ \\
\hline Medium before centrifugation & $1.9 \times 10^{6}$ & $16 \cdot 0$ & $8.0 \times 10^{8}$ \\
\hline $\begin{array}{l}\text { Medium, supernatant from } 65 \mathrm{~min} \text {. } \\
\text { at } c .14,000 \mathrm{rev} . / \mathrm{min} \text {. }\end{array}$ & $2.0 \times 10^{5}$ & $12 \cdot 3$ & $6.6 \times 10^{8}$ \\
\hline Cell debris before centrifugation & $1.0 \times 10^{5}$ & $76-2$ & Not assayed \\
\hline Cell debris supernatant from & $1.4 \times 10^{4}$ & $83 \cdot 0$ & Not assayed \\
\hline
\end{tabular}

from plaque-forming units, and to indicate a method for separating $\mathrm{T}$ from the bulk of the complement-fixing activity in order to study the serological nature of $\mathbf{T}$.

The cell debris had a high complement-fixing activity which was not deposited on centrifuging, and had a low plaque-forming activity $90 \%$ of which 
was deposited. From the medium containing released virus $c .90 \%$ of the infectivity was also deposited, while the complement-fixing activity of the supernatant dropped by about $20 \%$. The $\mathbf{T}$ content of the tissue culture fluid was also decreased by $20 \%$ on centrifuging.

It can be concluded that the interfering activity characteristic of $T$ was present in the $8 \mathrm{hr}$. yield of undiluted passage virus and had a much smaller sedimentation constant than the infective virus. Little quantitative significance can be attached to the differences in complement fixing activity or $\mathbf{T}$ content before and after centrifuging the preparations; they indicate that $\mathrm{T}$ is not readily separated from virus antigen by centrifugation, precluding for the present any identification of $T$ with virus serological activity because of probable contamination with soluble antigen (Bradish, Brooksby \& Dillon, 1956).

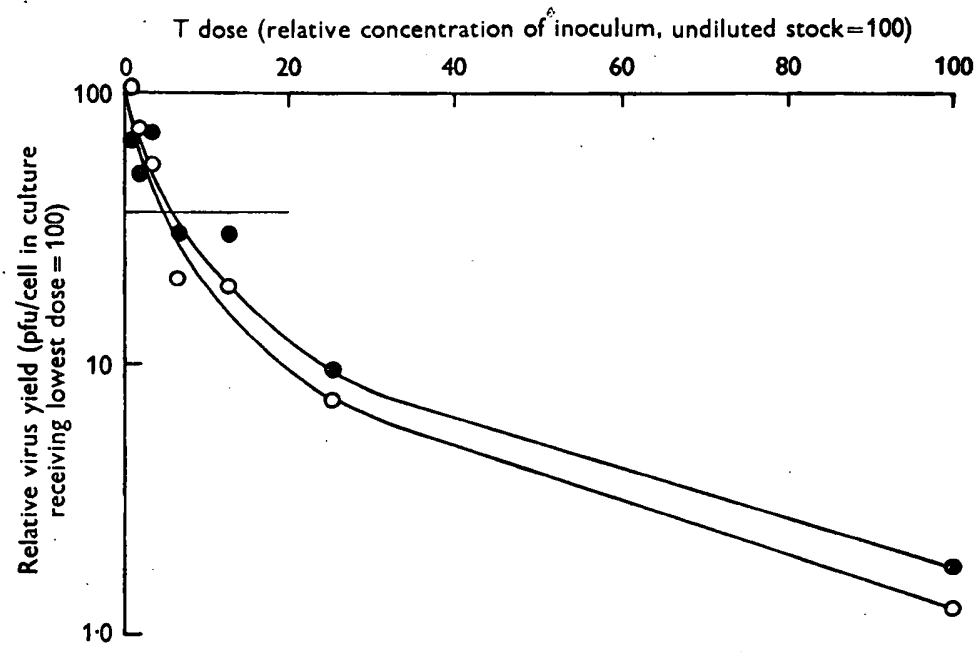

Fig. 3. Relation between yield and inoculum dilution for a T-containing stock before $(O)$ and after (O) removal of $90 \%$ of the plaque-forming units by centrifugation (for details see Table 6). Serial dilutions of the two samples were added to monolayers in $0.5 \mathrm{ml}$. amounts; and $5 \mathrm{ml}$. medium added after $30 \mathrm{~min}$. adsorption. Medium was harvested for assay after $22 \mathrm{hr}$. Relative yield is calculated on the basis of $2 \times 10^{7}$ cells/monolayer, although not all cells yield virus.

\section{DISCUSSION}

These results provide a little more information about the way in which the agent $T$ excludes infective virus, and about the properties of the $T$ particle itself. The exponential relation between dose of $T$ and yield of virus at low doses indicates that only one $T$ particle needs to be adsorbed to a cell for infective virus to be excluded. This high efficiency is quite different from the heterotypic interference of dilute passage vesicular stomatitis virus (Cooper, $1958 b$ ) where, although exclusion occurs, interfering and challenge virus appear to compete, and adsorption of many interfering particles is needed to exclude a single challenge particle; this may reflect differing rates of 
establishing exclusion and infection. However, at high doses of undiluted passage virus $\mathbf{T}$ does not protect as many cells as would be expected, perhaps because more cells receive infective virus before $\mathrm{T}$ has had time to establish itself. Nevertheless, even when all cells have received infective virus at an early time (Fig. 1) the relationship is still linear; thus although fewer cells have received $\mathbf{T}$ in time so that fewer cells are protected, the protection is still efficient in the sense that only one particle appears to be adequate.

The presence of so much $T$ component in the medium $8 \mathrm{hr}$. after infection (Table 6) means that the production and release of $\mathbf{T}$ must be broadly coincident with that of infective virus.

The homotypic interfering ability of $\mathbf{T}$ differs from the infectivity of intact virus in its much greater stability to heat and u.v. inactivation, but resembles the heterotypic interfering ability of intact virus in this respect. It is interesting that, in heterotypic tests, $T$ was not neutralized by antiserum. $T$ is also much less easily sedimented in the centrifuge than is virus, indicating that it is smaller, or less dense, or both. Its consequent contamination with soluble antigen has impeded serological identification as 'virus' by this means.

The formation of $\mathrm{T}$ by undiluted passage (Cooper \& Bellett, 1959) suggested an analogy with incomplete influenza virus, and several other properties of $\mathrm{T}$ support this idea. However, most of the properties found are also shared with influenza interferon (Isaacs \& Lindenmann, 1957); for example, all three have lower sedimentation constants than infective virus (Gard, von Magnus, Svedmir \& Birch-Andersen, 1952; Isaacs, Lindenmann \& Valentine, 1957) and all are relatively insensitive to heat or u.v. inactivation (Paucker \& Henle, 1958; Burke \& Isaacs, 1958; Isaacs, Lindenmann \& Valentine, 1957). Interferon might be expected to be found after undiluted passage of influenza virus because of the presence of more heat-inactivated virus than in dilute passage; heat-inactivated virus stimulates formation of interferon (Isaacs \& Lindenmann, 1957). None of the three forms is transmissible by itself, but interferon, like $T$ and incomplete influenza virus, should be transmissible in indefinite subculture provided that it is passed with appropriate amounts of infective virus. Neither $\mathbf{T}$ nor interferon (Isaacs, Lindenmann \& Valentine, 1957) is sensitive to immune serum; precisely comparable data seem to be unavailable for interference by incomplete influenza virus, although one might expect it to differ in this respect. Interferon (Isaacs, 1959) and T are not visibly cytotoxic by themselves; incomplete influenza virus is also probably nontoxic (von Magnus, 1954). Although incomplete influenza virus requires an 18-24 hr. interval before challenge to establish maximum interference, appreciable interference occurred after $1 \mathrm{hr}$. (von Magnus, 1954); interferon' requires several hr. incubation at $37^{\circ}$ for its effect to be maximal (Isaacs, 1959). $\mathrm{T}$ probably establishes most of its interference within $1 \mathrm{hr}$. although there was evidence that interference improved for a few hours after. It is difficult to compare the rates of development of interference in such different systems, but it seems that $\mathbf{T}$ resembles interferon more than incomplete influenza virus in this respect.

Interference in influenza virus is undoubtedly a complex thing, and may 
involve even more components than those already discovered. At present there is unfortunately not enough evidence to conclude much about $\mathbf{T}$ by analogy with influenza virus; $T$ could be an incomplete form, or an interferon, or some other entity quite different from these, although where comparison is possible there is more resemblance with interferon, particularly in its slow rate of sedimentation in the centrifuge.

\section{REFERENCES}

Bradish, C. J., Brooksby, J. B. \& Dillon, J. F. (1956). Biophysical studies of the virus system of vesicular stomatitis. J. gen. Microbiol. 14, 290.

BrooksBy, J. B. (1952). The technique of complement fixation in foot-and-mouth disease research. Rep. agric. Res. Coun. Series No. 12, H.M. Stationery Office.

Burke, D. C. \& IsAaCs, A. (1958). Further studies on interferon. Brit. J. exp. Path. . 39, 78.

Cooper, P. D. (1957). Some characteristics of vesicular stomatitis virus growthcurves in tissue culture. J. gen. Microbiol. 17, 327.

COOPER, P. D. (1958a). 'Shortened latency' as a result of multiple infection by vesicular stomatitis virus in chick cell culture. J. gen. Microbiol. 19, 340.

Cooper, P. D. (1958b). Homotypic non-exclusion by vesicular stomatitis virus in chick cell culture. J. gen. Microbiol. 19, 350.

Cooper, P. D. \& Bellett, A. J. D. (1959). A transmissible interfering component of vesicular stomatitis virus preparations. J. gen. Microbiol. $21,485$.

Gard, S., Magnus, P. von, Svedmir, A. \& Birch-Andersen, A. (1952). Studies on the sedimentation of influenza virus. Arch. ges. Virusforsch. 4, 591.

IsaAcs, A. (1959). Viral interference. Symp. Soc. gen. Microbiol. 9, 102.

IsaAcs, A. \& Lindenmann, J. (1957). Virus interference, I. The interferon. Proc. roy. Soc. B, 147, 258.

Isaacs, A., Lindenmann, J. \& Valentine, R. C. (1957). Virus interference, II. Some properties of interferon. Proc. roy. Soc. B, 147, 268.

Magnus, P. von (1951). Propagation of the PR 8 strain of influenza virus in chick embryos. 2. The formation of 'incomplete' virus following inoculation of large doses of seed virus. Acta path. microbiol. scand. 28, 278.

Magnus, P. von (1954). Incomplete forms of influenza virus. Advanc. Virus Res. 2, 59.

Paucker, K. \& Henle, W. (1958). Interference between inactivated and active influenza viruses in the chick embryo. II. Interference by incomplete forms of influenza virus. Virology, 6, 198.

(Received 1 April 1959) 